\title{
Clinically detection of foot and mouth disease at Kapasia upazila under Gazipur dristrict in Bangladesh
}

\author{
M. A. Alam, M. R. Amin, T. K. Paul and M. K. Rizon ${ }^{1}$ \\ Department of Physiology and Pharmacology and ${ }^{1}$ Department of Statistics, Patukhali Science \& Technology \\ University, Dumki, Patuakhali, Bangladesh, E-mail: ashraful00051@gmail.com
}

\begin{abstract}
Clinical detection of Foot and Mouth Disease in the cattle which study was carried out in Kapasia upazila under Gazipur district during from February 2011 to January 2012 and identifying the potential risk factors associated with the studies in Kapasia, Gazipur. A total of 315 infected cattle of different age, sex were examined in the upazila veterinary development center of Kapasia in Gazipur district. Total $86(27.30 \%)$ cattle were infected with FMD on the basis of clinico-epidemiological determinants. The effect of season, Breed, Age, and sex of cattle on the incidence of the disease was discussed. It was observed that rural farming system (30.43\%) was more susceptible than intensive farming $(21.30 \%)$ system of cattle. Old animals $(33.15 \%)$ were more susceptible than adult $(21.81 \%)$ and young $(15.71 \%)$. The prevalence of disease was found significantly $(P<0.05)$ higher in male $(33.65 \%)$ than in female $(24.17 \%)$. It was observed that local breed cattle $(35.48 \%)$ were more susceptible than cross-breed cattle $(15.50 \%)$. Seasonal variation of the disease was significant in the study area. The infection was less in summer (11.63\%) and increasing in rainy season (25.58\%) but gradually increased in late period of winter season (62.80\%). This report will help to prioritize and control strategies against Foot and Mouth diseases from Kapasia upazila at Gazipur District in Bangladesh.
\end{abstract}

Keywords: FMD, Clinico-Epidemiological, Cattle, Prevalence, Risk Factors

\section{Introduction}

Foot and mouth disease (FMD), usually called Apthus fever, is an acute, febrile, highly contagious and sometimes fatal viral disease of almost all the cloven-hoofed domestic animals, cattle, buffalo, sheep, goat and swine (OIE, 2009). It belongs to the family Picornaviridae (Mumford, 2007), Aphto virus genus, and presents seven serotypes and more than sixty subtypes according to lowa State University. It is a non-enveloped, single stranded, positive sense RNA virus, approximately 8,500 bases surrounded by four structural proteins (VP 1-4) to form an icosahedral capsid (Rueckert, 1996). There are seven FMD virus serotypes namely; O, A, C, SAT 1, SAT 2, SAT 3 and Asia 1. Infection with one serotype does not confer immunity against another (OIE, 2009). The virus causes a highly contagious disease that affects a wide range of domestic and wild animal species. This, combined with the high variability of the virus, determines that control of FMD virus infections is challenging and extremely expensive ( $\mathrm{O}$ Zabal and $\mathrm{N}$ Fondevila, 2013). The foot and mouth disease virus (FMDV) also affects more than 70 species of wild animals including deer, antilope (Fenner et al., 1993). In animals with a history of vesicular disease with fever; the detection of FMDV in samples of vesicular fluid, epithelial tissue, esophageal-pharyngeal sample, milk, or blood is sufficient to establish a diagnosis. Diagnosis may also be established by the detection of FMDV in the blood, heart or other organs in fatal cases. A myocarditis may be seen in a proportion of fatal cases (OIE, 2009). Outbreak of this disease causes severe economic losses to the livestock industries in terms of loss of draft power, meat and milk production, infant and adult animal mortality (Belsham and Bøtner, 2015; Chowdhury et al., 1993; Zinnah et al., 2010). An investigation was carried out by Chowdhury et al., 1993 in Bangladesh and their findings was, the morbidity due to FMD in cattle around $35.5 \%$, in buffaloes $23.3 \%$ and in sheep $4.8 \%$, and mortality rate, especially in calves, had been found to be about $50.9 \%$ in outbreak areas. In Bangladesh annual loss due to FMD has been estimated at about US $\$ 125$ million per year (Sil and Taimur, 2000). FMD appears in cattle of Bangladesh either generally in endemic or sometime in epidemic form. Amongst the livestock disease, FMD is thought to be the most dreadful one owing to its fierce pathogenicity and complexity in controlling it. Occurrence of FMD also varied month to month and season to season with higher seasonal incidence for September, October, November and April. It was found that movement of livestock for different purpose that has been considered as the cause an increasing secular trend (Kamaruddin and Pandit, 1988). The incidence of 
the disease was recorded highest in 1990, out of 64 districts FMD epidemic was broken out in 55. During that period the economic loss was due to all out production loss of cattle by the outbreak of FMD (Ahmed, 1993). The losses in draught cattle due to FMD in the district of Gazipur was losses of working days (6 to 19 days with an average of 12 days), body weight loss ( 7 to $20 \mathrm{~kg}$ with an average of $15 \mathrm{~kg}$ ), and edible meat loss (average TK. 144.0 /animal), draught energy wastage average 12.48 kilo watt hr/animal, and land left uncultivated average .72/ animal (Rahman et al., 1985). A lot of epidemiological and molecular research works have been conducted on FMD virus but in clinical aspects has few studied in Bangladesh (Islam et al, 2000; Howlader et al., 2004; Sarker et al., 2011; Hossen et al., 2014; Rahman et al., 2015) and in the world (Edwards, 2004; Durand et al., 2008; Fernandez et al., 2008; Ryan et al., 2008; Huang et al., 2011). There is no published data so far on prevalence of FMD in Gazipur district of Bangladesh although this region has huge number of livestock population. Due to the high economic loss and zoonotic significant of FMD it is important to know the prevalence of FMD in order to take necessary measures against this disease in a particular area. So, the present study was undertaken to identify and determine the outbreak of FMD infection in terms of relation with farming system, age, sex, breed, seasonal influence and epidemiological data that the findings of the study could be used to adopt effective disease management and control strategies in Bangladesh.

\section{Materials and Methods}

The study was conducted at upazila Veterinary Development Centre of Kapasia upazila in Gazipur District during from February 2011 to January 2012. A number of FMD outbreaks in cattle appeared in Kapasia upazila under Gazipur district. A total number of 315 infected cattle of different age, sex breed and season were examined. Among them 86 cattle were confirmed. On the basis on clinical history collected from owner and clinical findings from the affected cattle according to Rosenberger (1979), Samad (1988) and Gleeson et al., (2003). Inspection, palpation, percussion, auscultation, extension and flexion of limbs methods were used to examine the affected animal described by Kelly (1979) and Samad (1988). Pre-set questionnaire was filled contains information regarding demographic (age, sex, breed, seasonal influence) management, previous disease and preventive measures during examination. Data recorded during sampling and laboratory findings were entered and stored in MS-Excel. The data were thoroughly screened for errors and properly coded before being subjected to statistical analysis using the Statistical Package for Social Sciences (SPSS) version 20.0 statistical software. (SPSS, Inc., Chicago, IL, USA). The Pearson chi-square $\left(\left(x^{2}\right)\right.$ test was used to compare categorical data, and to evaluate the difference in prevalence between groups. All $\mathrm{P}$ values were based on a two-sided test of statistical Significant at $p<0.01$ (Sarkar et al., 2011).

\section{Results}

A total of315 infectious disease cattle were examined in this study period, among them 86 case was recorded and calculated and confirmed Foot and Mouth Diseases by clinic-epidemiological examination of infected animal. The prevalence rate was $27.30 \%$ among the infected individual.

The variation in the rate of prevalence might be due to difference in animal rearing system and age, breed of the animal and seasonal variation in Bangladesh.

Table 1, it could be concluded that rural farm (30.43\%) are more susceptible then intensive farming $(21.30 \%)$ system of cattle. Older animals $(33.15 \%)$ are more susceptible than adult $(21.81 \%)$ and young animals $(15.71 \%)$. The prevalence of disease was found significantly higher in male $(33.65 \%)$ than in female $(24.17 \%)$. It is observed that local breed cattle $(35.48 \%)$ are more susceptible than cross-breed cattle $(15.50 \%)$.

In Table 2 shows that the infection is less in summer season $(11.63 \%)$ than rainy season $(25.58 \%)$ but more prevalence in winter season $(62.80 \%)$. The clinical prevalence of FMD $(p<0.01)$ gradually increased from the month of May and then decreased from the month of December. Although the occurrence of FMD case recorded in though out the year 2011 but the attack rate of it gradually increased from the May $(3.49 \%)$ and high prevalence in November (29.07\%) but decreased from the month of December $(12.79 \%)$. 
Table 1. Clinically detection of FMD in relation to farm management systems, age, sex and breed of cattle in Kapasia upazila at Gazipur District

\begin{tabular}{|c|c|c|c|c|c|c|}
\hline \multicolumn{2}{|c|}{ Variables } & $\begin{array}{c}\text { Animal } \\
\text { Examined }\end{array}$ & $\begin{array}{c}\text { Animal } \\
\text { Infected }\end{array}$ & $\begin{array}{c}\text { Percentage } \\
\text { (\%) }\end{array}$ & $\begin{array}{l}\text { Chi-square } \\
\text { value }\end{array}$ & $P$ value \\
\hline \multirow{5}{*}{$\begin{array}{l}\text { Farm Management } \\
\text { Systems } \\
\text { Age }\end{array}$} & Rural Household Farm & 207 & 63 & $30.43^{*}$ & $18.605^{\mathrm{a}}$ & $P<.001$ \\
\hline & Intensive farm & 108 & 23 & 21.30 & & \\
\hline & Young ( 1 to $\leq 2 \mathrm{yrs}$ ) & 70 & 11 & 15.71 & & \\
\hline & Adult (2 to $\leq 4$ yrs.) & 55 & 12 & 21.81 & $61.618^{\mathrm{a}}$ & $P<.001$ \\
\hline & Old (4 yrs) & 190 & 63 & $33.15^{*}$ & & \\
\hline \multirow[t]{2}{*}{ Sex } & Male & 105 & 35 & $33.65^{*}$ & $2.977^{\mathrm{a}}$ & $\mathrm{P}<.083$ \\
\hline & Female & 211 & 51 & 24.17 & & \\
\hline \multirow[t]{2}{*}{ Breed } & Indigenous/ local & 186 & 66 & $35.48^{*}$ & $24.605^{\mathrm{a}}$ & $\mathrm{P}<.001$ \\
\hline & Crossed & 129 & 20 & 15.50 & & \\
\hline
\end{tabular}

Table 2. Occurrence of FMD in relation to seasons of Kapasia upazila at Gazipur district

\begin{tabular}{|c|c|c|c|c|c|c|}
\hline Season Name & $\begin{array}{l}\text { Name of the } \\
\text { Months }\end{array}$ & $\begin{array}{c}\text { Animal } \\
\text { Infected }\end{array}$ & Total & $\begin{array}{c}\text { Percent } \\
\text { (\%) }\end{array}$ & $\begin{array}{l}\text { Chi-square } \\
\text { value }\end{array}$ & $P$ value \\
\hline \multirow[t]{3}{*}{ Summer } & February/ 2011 & 3 & & \multirow[b]{3}{*}{11.63} & \multirow{10}{*}{$36.093^{a}$} & \multirow{11}{*}{$P<.001$} \\
\hline & March/ 2011 & 2 & & & & \\
\hline & $\begin{array}{l}\text { April/ } 2011 \\
\text { Mav/ } 2011\end{array}$ & $\begin{array}{l}2 \\
3\end{array}$ & 10 & & & \\
\hline \multirow[t]{3}{*}{ Rainy } & June/ 2011 & 5 & & & & \\
\hline & July/ 2011 & 4 & & & & \\
\hline & $\begin{array}{l}\text { August/ } 2011 \\
\text { September/ } 2011\end{array}$ & $\begin{array}{l}5 \\
8\end{array}$ & 22 & 25.58 & & \\
\hline \multirow[t]{4}{*}{ Winter } & October/ 2011 & 12 & & & & \\
\hline & November/ 2011 & 25 & & & & \\
\hline & December/ 2011 & 11 & & & & \\
\hline & January/ 2012 & 6 & 54 & 62.80 & & \\
\hline Feb 2011- January 2012 & & & 86 & & & \\
\hline
\end{tabular}

\section{Discussion}

A total of 315 infectious disease cattle were examined in this study period, among them 86 case was infected with Foot and Mouth Diseases and prevalence rate was $27.30 \%$ among the infected individual. The finding of present study is in agreement with (Chowdhury et al., 1994) who reported 35.5\% prevalence of FMD in cattle in Bangladesh,(Melo et al., 2003) who reported 22.89\% prevalence of FMD in cattle in South Asia, prevalence of FMD in cattle was $63.41 \%$ at Baghabari (Hawlader et al., 2004), (Mannan et al., 2009)reported24.52\% at meghna and comilla, in Bangladesh. On the other hand, the findings of (Sarker et al., 2011) reported $25.07 \%$ prevalence of FMD in Rajshahi, Bangladesh and (Rahman et al., 2015) reported the prevalence of FMD was $37.56 \%$ at Magurasadar, Magura, Bangladesh. The variation in the rate of prevalence might be due to difference in animal rearing system and age, breed of the animal and seasonal variation in Bangladesh.

\section{FMD in relation to Farming System of affected Cattle}

The different farming system of cattle and its association with Foot and Mouth Disease outbreak in our study area was presented in Table 1. In the present study the occurrence of FMD was found more in rural household farm (30.43\%) then Intensive farm (21.30\%) Similar study was reported by (Mannan et al., 2009). They found prevalence $25.83 \%$ in rural household farming system and $22.55 \%$ in intensive farming system and Similarly Sarker et al. (2011) have reported higher prevalence $(26.03 \%)$ of FMD in rural household farm compared to intensive farm. 


\section{FMD in relation to age}

The age of animals was analysed in three categories. The prevalence of FMD in cattle with age categories <2 years, between 2 and 4 years and above 4 years was found to be $15.71 \%, 21.81 \%$ and $33.15 \%$, respectively (Table 1$)$. There was a statistically significant different $(p<0.05)$ in prevalence associated with age of cattle. The occurrence of FMD in old age cattle of this study is supported by the study of (Sarker et al., 2011) who reported higher prevalence in old $(36.53 \%)$ compared to adult $(22.22 \%)$ and young $(8.08 \%)$. However the occurrence of FMD was higher in old animal in this study which is similar to other studies of (Mannan et al., 2009); (Sarker et al., 2011) except study of (Rahman et al., 2015) who reported higher prevalence in adult $(46.98 \%)$ compared to young $(18.07 \%)$ and old (34.94\%).The reasons of increased susceptibility to old cattle were due to malnutrition, poor immunity and poor management system.

\section{FMD in relation to sex}

The results showed that the prevalence of FMD was significantly $(p<0.05)$ higher in male $(33.65 \%)$ than female $(24.17 \%)$ indicating that the males were more susceptible to FMD than female (Table 1$)$. The result is similar according to the study of (Mannan et al., 2009); (Sarker et al., 2011) and (Rahman et al., 2015). The findings of present study significantly differ from the findings of (Hawlader et al., 2004) who reported FMD occurrence is higher in females (68.01\%) than in males $(68.09 \%)$.

\section{FMD in relation to breed}

In the present study the occurrence of FMD was found more in local cattle (35.48\%) than crossed breed cattle $(15.50 \%)$ showed in Table 1 that indicate indigenous breed is more susceptible than crossed breed. These finding are similar to studies of Rahman et al., 2015. The higher occurrence of FMD in local cattle due to household or free rearing system of cattle that enhance spread of the disease easily then cross breed animal. Because the rearing of crossed breed animal is intensive or semi intensive system which may decrease the chance of occurrence of the disease in animal.

\section{FMD in seasonal variation}

The result in the present study showed the significant seasonal variation on the occurrence of FMD in cattle of kapasia upazila at Gazipur district (Table 2). FMD was higher prevalent in winter season followed by rainy season in this study area and low in summer season. Highest prevalence $(37.87 \%)$ was observed in November followed by October (31.57\%) and December (31.42\%). The result supports the earlier report of (Prased et al., 1981); (Kamaruddin and Pandit, 1988). The occurrence of FMD started to increase at the end of summer season and was peak in late winter season. During our study period the Eid-Ul-Fitar and Eid-Ul-Azaha was held then disease may be spreaded from the cattle market after Eid, Also heavy rainfall occurred at that time. The results of this study are partially supported by the study of (Sarah et al., 2002); (Mannan et al., 2009); (Sarker et al., 2011) and (Rahman et al., 2015).

\section{Conclusion}

Present study confirmed by clinical diagnosis, the circulating FMD in kapasia at Gazipur in Bangladesh. So, proper control measures against Foot and Mouth disease is needed to prevent the FMD spread and economic losses from treatment and death of the affected animals.

\section{Acknowledgements}

We thank to Upazila Livestock Officer Dr. Akhil Chandra for his best co-operation during study in Upazila Livestock Development Centre, Kapasia in Gazipur. 


\section{References}

Ahmed. 1993. Foot and Mouth Disease in Yak. Indian Veterinary Journal, 58: 421.

Belsham, G.J. and Bøtner, A. 2015. Use of recombinant capsid proteins in the development of a vaccine against the foot-andmouth disease virus. Virus Adaptation and Treatment, 7: 11-23.

Chowdhury, S.M.Z.H., Rahman, M.F., Rahman, M.B. and Rahman, M.M. 1993. Foot and mouth disease virus and its effects on morbidity, mortality, milk yield and draugt power in Bangladesh. Asian-Australasian Journal of Animal Sciences, 6(3): 423-426.

Chowdhury, S.M.Z.H., Rahman, M.B., Rahman, M.F. and Rahman, M.M. 1994. Strain of FMD virus in different district in bangladesh. Pakistan Veterinary Journal, 14:89-91.

Durand, S., Murphy, C., Zhang, Z. and Alexandersen, S. 2008. Epithelial Distribution and Replication of Foot and Mouth Disease Virus RNA in Infected Pigs. Journal of Comparative Pathology, 139(2-3): 86 - 96.

Edwards, J.R. 2004. Strategy for the control of foot-and-mouth disease in South East Asia (SEAFMD). Journal of Developmental Biology, 119: 423 - 431.

Fenner, F.J., Gibbs, P.J., Murphy, F.A., Rott, R., Studdert, M.J. and White, D.O. 1993. Virus interacting layered phyllosilicates and methods of inactivating virus on animate and inanimate surfaces. Academic Press, New York. Veterinary Virology, Pp: $403-430$.

Fernandez, J., Aguero, M., Romero, L., Sanchez, C., Belak, S., Arias, M., Sanchez-Vizcaino, J.M. 2008. Rapid and differential diagnosis of foot-and-mouth disease, swine vesicular disease, and vesicular stomatitis by a new multiplex RT-PCR assay. Journal of Virological Methods, 147: 301 - 311

Gleeson, L.J., Bauer, K. and Aidaros, H.A. 2003. A review of the status of FMD in South East Asia and approach to control and eradication. Science and Technology Research, 21(3): 465-475.

Hossen, M.L., Ahmed, S., Khan, M.F.R., Rahman, M.T., Saha, S., Nazir, K.H.M.N.H., Rahman, M., Islam, M.A. and Rahman, M.B. 2014. Typing of Foot and Mouth Disease Virus Circulating in Bangladesh by Reverse Transcription Polymerase Chain Reaction. Journal of Veterinary Advances, 4(12):778-785. DOI:10.5455/jva.20141221083415.

Howlader, M.M.R., Mahbub-E-Elahi, A.T.M., Habib, S., Bhuiyan, M.J.U., Siddique, M.A.B., Hai, M.A. and Hossain, M.G. 2004. Foot and mouth disease in Baghabari milk-shed area and its economic loss in Bangladesh. Journal of Biological Sciences, 4: $581-583$.

Huang, X., Li, Y., Fang, H. and Zheng, C. 2011. Establishment of persistent infection with foot-and-mouth disease virus in BHK21 cells. Virology Journal, 14(8): 169.

Islam, M.A., Rahman, M.M., Adam, K.H. and Marquardt, O. 2000. Epidemiological implications of the molecular characterization of foot-and mouth disease virus isolated between 1996 and 2000 in Bangladesh. Virus Genes, 23: 203-213.

Kelly, W.R. 1979. Veterinary Clinical Diagnosis, Second Ed. (1974). Bailliere, Tandall and Cassel Ltd. London, 39-102.

Kamaruddin, K.M. and Pandit, K.K. 1988. Pattern of Foot-and-Mouth disease virus infection in cattle of Bangladesh. Bangladesh Veterinary Journal, 5: 54-58.

Mannan, M.A., Siddique, M.P., Uddin, M.Z. and Parvez, M.M. 2009. Prevalence of foot and mouth disease (FMD) in cattle at Meghnaupazila in Comilla in Bangladesh. Journal of Bangladesh Agricultural University, 7(2): 317-319.

Melo, E., Saravia, V. and Astudillo, V. 2003. A Review of the FMD in countries of South Asia. Science and Technology Review, 21(3): 429-436.

Mumford, J.A. 2007. Vaccines and viral antigenic diversity. Revue Scientifiqueet Technique, 26: 69-90.

OIE. 2009. Principles of Veterinary Vaccine Production. Internation Manual of Diagnostic Tests and Vaccines for Terrestrial Animals. Version adopted May 2006, Chapter 1.1.7.

Prasad, J., Uoshi, S.V. and Rekib, A. 1980. Studies on the clinic - pathics of grazing animals in tropics - corneal opacity syndrome. Indian Veterinary Journal, 57: 310 - 315

Rahman, A., Ahmed, J.U. and Islam, A. 1985. Quantification of losses among draught cattle due to foot-and-mouth disease: a case study in Mymensingh District, Bangladesh. Indian journal of animal sciences, 55(1): $25-26$.

Rahman, M.M., Jalil, M.A., Hossain, K.M.M., Alam, K.J., Salam, R. and Reza, M.A. 2015. Occurrence of foot and mouth disease in cattle in Magura district of Bangladesh. International Journal of Natural and Social Sciences, 2(3): 1- 4.

Reosenberger, A. 1979. Preliminary observations of placental retention in cows. Medycyna Weterynaryjin, 32 : 92

Rueckert, R.R. 1996. Picornaviridae: the virus and their replication. In B. N. Fields, D. M. Knipe, and P. H. Howley (ed.), Fields Virology, $3^{\text {ra }}$ edn., Lippincott-Raven Publishers, Philadelphia, Pa. pp. $609-654$

Ryan, E., Horsington, J., Brownlie, J. and Zhang, Z. 2008. Foot-and-mouth disease virus infection in fetal lambs: tissue tropism and cytokine response. Journal of Comparative Pathology, 138(2-3): 108 - 20. 
Samad, M.A. 1988. Veterinary clinicial Guide. $2^{\text {nd }}$ edn., Lyric-Epic Prokasoni, BAU Campus, Mymensingh, pp. 572-580.

Sarah, K., Geale, D.W. and Kltching, P. 2002. Duncan vaccination against FMD: The implication for Canada. The Candian Veterinary Journal, 43(5): 349-354.

Sarker, S., Talukder, S., Haque, M.H., Islam, M.H. and Gupta, S.D. 2011. Epidemiologicalstudy on foot-and-mouth disease in cattle: Prevalence and risk factors assessment in Rajshahi, Bangladesh. Wayamba Journal of Animal Science, March issue: $71-$ 73.

Sil, B.K. and Taimur, M.J.F.A. 2000. ELISA based techniques for the identification of foot-and-mouth disease virus and vaccine evaluation in Bangladesh. International Atomic Energy Agency, 31(1) 49-56.

Zabal, O. and Fondevila, N. 2013. Selection of highly susceptible cell lines to Foot and Mouth Disease virus infection. Open Journal of Veterinary Medicine, 3: 263-266.

Zinnah, M.A., Islam, M.T., Rahman, M.M., Hossain, M.T., Bari, M.R., Haque, M.H., Khan, M.S.R. and Islam, M.A. 2010. Standardization of multiplex reverse transcription-polymerase chain reaction and typing of foot-and-mouth disease virus prevalent in Bangladesh. Bangladesh Journal of Veterinary Medicine, 8 (2): $149-155$. 